\title{
ANALISIS INDEPENDENSI ODITUR MILITER DALAM MELAKSANAKAN FUNGSINYA DI ODITURAT MILITER III-14 DENPASAR DENGAN BERLAKUNYA KEBIJAKAN RENCANA TUNTUTAN
}

\author{
Oleh :
}

Misran Wahyudi ${ }^{1}$

\begin{abstract}
Military Prosecuting Attorney is one of the main components in enforcing the criminal law in the military judicature system. Moreover, the Military Prosecuting Attorneys is as a prosecutor in the Indonesian National Armed Forces (TNI). Confidently, it has major function in demanding based on legitimating evidences in military court. Military Prosecuting Attorney can work its duty well, if it has independently in the function as general presector of Indonesian military court system. Afterwards, the first problem is wheter Military Prosecuting Attorney independently achieve its function in Oditurat Militer III-14 Denpasar by conducted the plan demans policy as of Military Prosecuting Attorney General Indonesian National Armed Forces? Whereas, the second problem is whether the efforts shoud be accomplished in establishing independent Military Prosecuting Attorney? This research was conducted by empirical legal research methods, and the study was a descriptive analytic research by using primary data and secondary data. Based on this research, it can be concluded that; first, Military Prosecuting Attorneys in Oditurat Militer III-14 Denpasar became less independent, it was occured because the implementation of the plan demand policy by Military Prosecuting General Attorney. It can be stated that the demand was only established by upper position and finally, the judgments are not merely according conscience. Secondly, Military Prosecuting Attorney attempt to independently in military justce system in three aspects such as technical field of prosecution, field supervision and control, as well as education and training.
\end{abstract}

Keywords: Military Prosecuting Attorneys, Independence, Functions

\section{PENDAHULUAN}

\subsection{Latar Belakang}

Sistem penegakan hukum pidana terpadu (intergrated criminal justice system) merupakan bagian dari sistem penegakan hukum, dan sistem penegakan hukum merupakan bagian dari kekuasaan kehakiman. $^{2} \quad$ Sistem peradilan pidana menurut Muladi merupakan suatu jaringan

Mahasiswa Magister Ilmu Hukum Universitas Udayana, Denpasar, Bali. Alamat Mess 3 Lanud Ngurah Rai Tuban, Kuta, Badung, Bali, email : misran_08hk@yahoo.co.id.

H.R. Abdussalam dan Adri Desasfuryanto, 2012, Sistem Peradilan Pidana, Penerbit : PTIK, Jakarta, hlm. 36 . (network) peradilan yang menggunakan hukum pidana materiil, hukum pidana formil maupun pelaksanaan pidana. ${ }^{3}$ Sejalan dengan konsep tersebut, penegakkan hukum pidana dalam sistem peradilan pidana militer akan berjalan dengan baik apabila aparatur penegak hukumnya bersinergi. Oditur Militer sebagai bagian dari aparatur penegak hukum dalam sistem peradilan militer di Indonesia memiliki peran yang sangat penting guna mendukung jalannya sistem

Romli Atmasasmita, 2010, Sistem Peradilan Pidana Kontemporer, Kencana Prenada Media Grup, Jakarta, hlm.5. 
tersebut. Fungsi utama Oditur Militer adalah melaksanakan kekuasaan negara di bidang penuntutan dengan memegang teguh nilainilai kejujuran, kebenaran dan keadilan.

Berdasarkan Pasal 47 dan Pasal 48 Undang-Undang RI Nomor 31 Tahun 1997 tentang Peradilan Militer, kewenangan atau kekuasaan Oditur Militer adalah melaksanakan kekuasaan negara di bidang penuntutan dan penyidikan di lingkungan TNI, serta dalam melaksanakan fungsi penuntutan berlandaskan pada asasnya Oditurat adalah satu tidak terpisah-pisahkan. SedangkanOditurMilitersecarakelembagaan sesuai Keputusan Panglima TNI Nomor Kep/24/VIII/ 2005 tanggal 10 Agustus 2005 tentang Pokok-Pokok Organisasi dan Prosedur Badan Pembinaan Hukum TNI, Oditurat Jenderal TNI (Otjen TNI) selaku Badan Penuntut Tertinggi di lingkungan TNI dalam pembinaan penyelenggaraan Oditurat berada di bawah Badan Pembinaan Hukum TNI disingkat Banbinkum TNI, namun demikian Otjen TNI yang dipimpin oleh seorang Oditur Jenderal TNI disingkat Orjen TNI bertanggung jawab secara teknis yustisial di bawah pengawasan Jaksa Agung RI selaku Penuntut Tertinggi di Negara Republik Indonesia melalui Panglima TNI. ${ }^{4}$ Selain melakukan penuntutan, tugas Oditur Militer adalah melaksanakan penetapan hakim dan putusan Pengadilan Militer yang telah memperoleh kekuatan hukum tetap, melakukan pengawasan terhadap pelaksananaan putusan pidanabersyarat, serta melaksanakan pemeriksaan tambahan guna melengkapi berkas perkara dari Penyidik

Keputusan Panglima TNI Nomor Kep/24/VII/2005 tanggal 10 Agustus 2005, hlm.18.
Polisi Militer (PM) sebelum dilimpahkan kepada pengadilan di lingkungan Peradilan Militer atau pengadilan di lingkungan Peradilan Umum yang berwenang disertai dengan surat dakwaan dan Keputusan Perwira Penyerah Perkara tentang penyerahan perkara. Dalam melakukan fungsi penuntutan Oditur Militer harus senantiasa memperhatikan norma-norma keagamaan, kemanusiaan, dan kesusilaan serta wajib menggali nilai-nilai hukum dan keadilan yang hidup dalam masyarakat dengan memperhatikan kepentingan pertahanan keamanan negara. Oditur Militer membuat surat tuntutan (requsitoir) secara tertulis yang akan dibacakan di persidangan, mencantumkan tuntutan terhadap terdakwa berupa penghukuman yang disusun berdasarkan pemeriksaan saksi, ahli, surat dan keterangan terdakwa . Hal ini sangat berbeda dengan surat dakwaan yang belum memuat ancaman pidananya pada saat melimpahkan berkas perkara ke Pengadilan Militer. Tuntutan Oditur Militer nantinya menjadi dasar bagi hakim untuk menjatuhkan putusan. Putusan hakim tanpa adanya tuntutan Penuntut berakibat putusan batal demi hukum. ${ }^{5}$

Bertitik tolak dari tugas, wewenang dan tanggung jawab yang diamanatkan oleh undang-undang, Oditur Militer selaku Penuntut di lingkungan TNI akan dapat menjalankan fungsinya dengan baik apabila memiliki independensi. Independensi terhadap Oditur Militer merupakan jaminan bagi tegaknya keadilan menjadi prasyarat bagi terwujudnya cita-cita negara hukum.

Fadzri, 2006, Rencana Tuntutan Bisa Jadi Komoditas, $\& \mathrm{i}=1004$-rencana-tuntutan-bisa-jadi-komoditas, (diakses tanggal 03 Mei 2014). 
Independensi sendiri memiliki padanan kata dengan "kemandirian", yang berarti tidak terpengaruh oleh pihak manapun dalam menentukan keputusan dan mengambil kebijakan, sehingga lembaga/organisasi yang memiliki predikat independen mempunyai kebebasan dalam menentukan misi yang diembannya. Prinsip independensi (the principle of independence) bagi Oditur Militer harus tercermin dalam hal pengambilan keputusan terhadap setiap perkara yang yang ditangani, terutama dalam tugas utamanya melakukan penuntutan, sehingga membawa lembaga Oditurat sebagai institusi yang berwibawa, bermartabat dan terpecaya.

Tolok ukur mengenai independensi dihubungkan dengan fungsi Oditur Militer selaku Penuntut di lingkungan TNI adalah dalam menjalankan tugas, wewenang dan tanggung jawabnya, Oditur Militer harus terbebas dari intervensi yang bersifat mempengaruhi dari pihak manapun, namun bukan bebas sebebas-bebasnya, tetapi tetap patuh kepada yang hak atau benar mengikuti aturan yang ada. Namun demikan independensi Oditur Militer menjadi kontra produktif dengan adanya kebijakan rencana tuntutan dari Orjen TNI yang dilaksanakan tidak sesuai dengan Peraturan Panglima TNI Nomor : Perpang/5/II/2009 tanggal 27 Februari 2009 tentang Petunjuk Administrasi Oditurat Dalam Penyelesaian Perkara Pidana. Sesuai Perpang/5/II/2009 dalam Bab $\mathrm{V}$ angka $28 \mathrm{~h}$ tentang tuntutan disebutkan bahwa Oditur melalui Kepala Oditurat Militer/Kepala Oditurat Militer Tinggi harus meminta petunjuk dan arahan Orjen TNI sebelum mengajukan tuntutan terhadap perkara pidana : a. Dalam Perkara :

1) Yang diancam hukuman lima tahun atau lebih, dan

2) Yang sifatnya menonjol.

b. Apabila akan menuntut bebas dari dakwaan atau lepas dari tuntutan.

Kebijakan rencana tuntutan oleh Oditur Jenderal dikeluarkan melalui Surat Telegram Orjen TNI Nomor : ST/20/2006 tanggal 22 Nopember 2006 dalam perkara pidana yang ancaman pidana penjara di atas 2 (dua) tahun 8 (delapan) bulan harus diajukan kepada Orjen TNI melalui Kepala Oditurat Militer atau Kepala Oditurat Militer Tinggi untuk mendapatkan persetujuan. Penekanan ulang kebijakan mengenai rencana tututan dilakukan oleh Orjen TNI berikutnya melalui Surat Telegram Nomor: ST/01/2009 yang isinya setiap Oditur Militer atau Oditur Militer Tinggi yang akan melakukan penuntutan terhadap Terdakwa agar terlebih dahulu meminta persetujuan Orjen TNI yang dituangkan dalam rencana tuntutan terhadap perkara yang ancaman pidananya dua tahun delapan bulan dan perkara yang ancaman pidananya dua tahun delapan bulan ke bawah, tetapi akan dituntut dengan hukuman tambahan pemecatan dari dinas militer, kecuali terhadap perkara desersi in absensia.

Kebijakan rencana tuntutan yang terbaru dari Orjen TNI adalah dengan dikeluarkannya Surat Telegram Nomor : ST/26/2012 tanggal 21 Desember 2012 yang isinya bahwa rencana tuntutan diajukan kepada Orjen TNI terhadap perkaraperkara:

a. Perkara yang akan dituntut kurang dari tiga bulan.

b. Perkara narkotika dan psikotropika. 
c. Perkara susila yang melibatkan Keluarga Besar TNI.

d. Perkara yang ancaman pidananya lebih dari dua tahun delapan bulan.

e. Perkara yang ancaman pidananya kurang dari dua tahun delapan bulan, tetapi akan dituntut dengan hukuman tambahan pemecatan kecuali perkara desersi in absensia.

f. Perkara yang dimintakan Petunjuk Orjen TNI untuk Tuppera atau Kumplin dan sesuai Petunjuk Orjen tetap diselesaikan melalui Dilmil/ Dilmilti.

Pelaksanaankebijakanrencanatuntutan yang tidak sesuai dengan Perpang/5/II/2009 tanggal 27 Februari 2009 dapat di lihat dari data rencana tuntutan yang ada pada Kantor Oditurat Militer III-14 Denpasar tahun 2012 dan 2013. Data rencana tuntutan tahun 2012 menunjukkan, bahwa dari 41 perkara pidana yang diajukan persetujuan rencana tuntutan kepada Orjen TNI hanya terdapat 5 perkara yang ancaman pidananya 5 (lima) tahun penjara atau lebih dan sisanya sebanyak 36 perkara ancaman pidananya kurang dari 5 (lima) tahun. Selanjutnya data rencana tuntutan tahun 2013 menunjukkan, bahwa dari 46 perkara pidana yang diajukan rencana tuntutan terdapat 8 perkara yang diancam dengan pidana penjara selama 5 tahun atau lebih, sedangkan sisanya sebanyak 38 perkara ancaman pidananya kurang dari 5 tahun.

Kemudian dari data perkara yang diajukan rencana tuntutan tahun 2012 dan 2013 jika digabungkan menjadi berjumlah 87 perkara, yang terdiri dari 13 perkara yang ancaman pidananya 5 (lima) tahun penjara atau lebih, sisanya sebanyak 74 perkara ancaman pidananya kurang dari 5 (lima) tahun. Sehingga dari rencana tuntutan Oditurat Militer III-14 Denpasar tahun 2012 dan 2013 tersebut, hanya 13 perkara yang seharusnya diajukan rencana tuntutan kepada Orjen TNI, sedangkan sisanya sebanyak 74 perkara tidak perlu diajukan rencana tuntutan karena adalah perkara-perkara yang ancaman pidananya 5 tahun atau lebih maupun perkara yang sifatnya menonjol saja.

Kebijakan pengajuan rencana tuntutan yang telah diberlakukan di seluruh Oditurat selama ini, apabila tetap diberlakukan, maka secara tidak langsung akan mengurangi independensi Oditur Militer dalam menjalankan tugas, wewenang dan tanggung jawabnya. Hal ini dikarenakan Oditur Militer selaku Penuntut yang seharusnya lebih mengetahui fakta-fakta hukum yang ada di dalam persidangan, tetapi dalam mengambil keputusan dalam perkara yang ditangani menjadi sangat tergantung pada keputusan atasannya. Keadaan seperti ini akan menjadi beban tersendiri bagi setiap Oditur, karena secara tidak langsung merupakan suatu bentuk intervensi dan pengekangan terhadap kewenangannyamengambilkeputusan sesuai hatinurani, serta tidak mengajari setiap Oditur Militer untuk mandiri dan bertanggung jawab secara penuh dalam perkara yang sedang ditanganinya. Selain dari pada itu dengan diberlakukannya kebijakan rencana tuntutan akan mempengaruhi efektivitas percepatan penyelesaian perkara, seringkali persidangan yang seharusnya dapat dilaksanakan tetapi harus tertunda karena persetujuan rencana tuntutan belum turun.

Menurut pendapat Kadiswasnis Otjen TNI Kolonel Chk Endro Nurwantoko, $\mathrm{SH} ., \mathrm{MH}$. pelaksanaan rencana tuntutan 
dimaksudkan menjadi satu alat kendali Orjen

TNI dalam melaksanakan pengendalian dan pengawasan penyelesaian perkara (sebagai fungsi kontrol) agar setiap Oditur Militer tidak berlaku semaunya sendiri dalam menentukan besaran tuntutan. Sesuai dengan Pasal 49 Undang-Undang Nomor 31 Tahun 1997 tentang Peradilan Militer, Oditur adalah satu dan tidak terpisahpisahkan dalam melaksanakan penuntutan. Hal tersebut maknanya adalah semua Oditur yang bertindak sebagai Penuntut di Persidangan Pengadilan adalah deputy public presecutor. Dengan kata lain ketika menjalankan penuntutan dia adalah "Alter Ego" personifikasi atau perlambangan dari Orjen TNI, sehingga harus dapat menampilkan ciri khas yang menyatu dalam tata pikir, tata laku dan tata kerjanya. ${ }^{6}$

\subsection{Perumusan Masalah}

Berdasarkan latar belakang masalah di atas, maka rumusan masalah adalah sebagai berikut :

1. Apakah Oditur Militer independen dalam melaksanakan fungsinya di Oditurat Militer III-14 Denpasar dengan berlakunya kebijakan rencana tuntutan?

2. Upaya-upaya apakah yang harus dilakukan untuk menjadikan Oditur Militer yang independen dalam menjalankan fungsinya sebagai Penuntut Umum TNI?

\subsection{Tujuan Penelitian}

\section{a. Tujuan Umum}

Untuk menganalisis dan mengkaji tentang independensi Oditur Militer dalam melaksanakan fungsinya selaku Penuntut Umum TNI pada sistem paradilan militer.

\section{b. Tujuan Khusus}

Untuk mengetahui dan menganalisis apakah Oditur Militer independen dalam melaksanakan fungsinya selaku Penuntut Umum di lingkungan TNI dengan berlakunya kebijakan rencana tuntutan dan menganalisis tentang upaya-upaya apasaja yang harus dilakukan dalam mewujudkan Oditur Militer yang independen dalam sistem peradilan militer.

\section{METODE PENELITIAN}

Penelitian ini menggunakan data, maka dengan sendirinya merupakan penelitian hukum empiris. ${ }^{7}$ Penelitian ini bersifat bersifat deskriptif analitik dengan menggunakan data primer dan data sekunder. Data primer diperoleh dari wawancara dengan narasumber yang terkait dan data rencana tuntutan Oditur Militer di Oditurat Militer III-14 Denpasar, pengambilan sampel dlakukan menggunakan purposive sampling. Sedangkan data sekunder diperoleh dari bahan hukum primer, bahan hukum sekunder dan bahan hukum terseier. Setelah data primer dan data sekunder lengkap, maka dilakukan analisis secara kualitatif menggunakan teori hukum yang telah ditentukan. Kemudian hasil analisis disajikan secara deskriptif analitis dalam

\footnotetext{
Mukti Fajar N.D. dan Achmad, Yulianto, 2007, Dualisme Penelitian Hukum, Pensil Komunika, Yogyakarta, hlm.32.
}

Endro Nurwantoko, 2012. "Mekanisme Rencana Penuntutan di Lingkungan Oditurat Jenderal TNI", Makalah pada Rakornis Babinkum TNI TA. 2012, Jakarta, hlm.2. 
bentuk uraian-uraian sehingga akan mampu memberi gambaran dan kesimpulan yang jelas sesuai rumusan masalah.

\section{HASIL DAN PEMBAHASAN}

3.1. Independensi Oditur Militer dalam melaksanakan fungsinya di Oditurat Militer III-14 Denpasar dengan berlakunya kebijakan rencana tuntutan.

Hakikat dari independensi atau kemandirian yang mendasar adalah memiliki arti bahwa seseorang mampu untuk menentukan sendiri secara bebas dalam mengambil keputusan, tetapi tetap terikat oleh suatu aturan. Menurut Franz Magnis Suseno, kebebasan di sini terbagi dalam dua jenis, yaitu kebebasan eksistensial dan kebebasan sosial. $^{8}$ Kebebasan eksistensial adalah terdiri dalam kemampuan manusia untuk menentukan dirinya sendiri yang sifatnya positif. Maksud dari konsep kebebasan ini adalah kebebasan tidak menekankan segi bebas dari apa, tetapi bebas untuk apa. Oleh sebab itu kebebasan terwujud secara positif dalam tindakan manusia yang disengaja dilakukan dengan maksud dan tujuan tertentu. Sedangkan hakekat kebebasan sosial berarti suatu keadaan di mana manusia tidak berada di bawah paksaan, tekanan atau kewajiban dan larangan dari pihak manusia lainnya. ${ }^{9}$

Independensi Oditur Militer dikaitkan dengan fungsi utamanya adalah melakukan penuntutan dalam sistem peradilan militer di Indonesia terbebas dari pengaruh dan bebas dari paksaan maupun rekomendasi.

Ahmad Kamil, 2012, Filsafat Kebebasan Hakim, Kencana Prenada Media Grup, Jakarta, hlm.149.

Ibid, hlm.155.
Jika Oditur Militer sebagai Penuntut Umum di lingkungan TNI dalam melakukan penuntutan tidak independent, tentunya akan berdampak kepada putusan hakim militer nantinya. Tujuan utama penuntutan oleh Oditur Militer selaku penuntut umum adalah untuk mencari dan mendapatkan kebenaran materiil, yaitu kebenaran yang selengkaplengkapnya dari suatu perkara pidana sesuai ketentuan hukum acara yang berlaku guna menentukan apakah orang yang didakwanya dapat dinyatakan bersalah.

Kewenangan yang dimiliki setiap Oditur Militer seharus dijalankan secara independen dari pengaruh siapapun, namun adanya kebijakan rencana tuntutan yang diberlakukan akan berpengaruh terhadap independensi setiap Oditur Militer. Oditur Militer yang menyidangkan perkara di Pengadilan Militer yang lebih mengetahui secara utuh jalannya persidangan dan mengetahui fakta-fakta yang terungkap dalam persidangan, tetapi pada saat akan membuat tuntutan pidana harus tergantung pada atasannya. Proses pembuatan rencana tuntutan oleh Oditur Militer sebagai Penuntut Umum dibuat secara singkat tentunya tidak mampu menggambarkan keseluruhan yang terjadi di persidangan, sehingga pertimbangan dalam membuat tuntutan oleh Oditur Militer yang menyidangkan perkara di Pengadilan Militer belum tentu juga sepenuhnya dipahami oleh atasan Oditur Militer.

Untuk mengetahui jawaban tentang independensi Oditur Militer dalam menjalankan fungsinya di Oditurat Militer III-14 Denpasar dengan berlakunya kebijakan rencana tuntutan, maka penulis mewancarai Oditur Militer yang bertugas di kantor Otmil 
III-14 Denpasar, antara lain :

a. Wawancara dengan Letkol Chk Sumantri, SH. pada hari Senin tanggal 8 Desember 2014 pukul 09.00 Wita.

Dari hasil wawancara dijelaskan bahwa Oditur Militer Sidang yang melaksanakan sidang di Pengadilan Militer tidak independen pada saat menjalankan fungsinya sebagai Penuntut Umum, yaitu ketika akan menjatuhkan tuntutan pidana harus membuat rencana tuntutan, atau setidak-tidaknya melaporkan kepada Kepala Oditurat Milter untuk mendapat persetujuan. Dengan adanya kebijakan rencana tuntutan yang merupakan fungsi kontrol, maka Oditur Militer dianggap belum profesional dan belum memahami tugas pokok dan fungsi (tupoksi) dalam menjalankan tugasnya selaku penuntut umum di lingkungan TNI.

Oditur Militer yang seharusnya lebih mengetahui fakta-fakta yang terjadi di persidangan Pengadilan Militer secara utuh, ketika selesai melakukan pemeriksaan terhadap terdakwa dan pada saat membuat tuntutan, keputusannya menjadi tergantung kepada pimpinan, sehingga keputusan yang diambil tidak murni dari hati nurani. Dicontohkan, ketika Oditur Militer mengajukan rencana tuntutan, besaran tuntutan pidana yang diajukan dalam rencana tuntutan, setelah turun tidak sama dengan rencana tuntutan dari Oditur Militer. Besaran tuntutan naik maupun kurang dengan tanpa diberi penjelasan. Oditur Militer sudah selayaknya diberi kebebasan dalam menentukan tuntutan, tetapi tetap mengedepankan kebebasan bertanggungjawab dengan apa yang dilakukan. b. Wawancaradengan Mayor Chk Reman, SH.,MH. pada hari Rabu tanggal 10 Desember 2014 pukul 13.00 Wita.

Hasilwawancara diperoleh keterangan, bahwa pada dasarnya Oditur Militer yang melaksanakan sidang pada saat melakukan pemeriksaan terhadap terdakwa, saksi dan alat bukti di persidangan dilakukan secara independen. Oditur Milter mempunyai keyakinan sendirikarena mengetahui suasana kebatinan pada saat melakukan pemeriksaan di persidangan Pengadilan Militer, namun dalam membuat tuntutan keputusan akhir ada pada pimpinan. Oditur Militer sangat berbeda dengan Hakim Militer, karena Hakim Militer terhadap putusan murni tidak bertanggung jawab pada kepala, namun secara individu langsung bertanggung jawab kepada Tuhan Yang Maha Esa.

Sehubungan dengan kebijakan rencana tuntutan dari Orjen TNI, hal ini karena tidak lepas dari asas Oditurat satu dalam melakukan penuntutan, yaitu supaya setiap Oditur Militer tidak keluar hal-hal yang telah diatur. Rencana tuntutan yang diajukan tidak semuanya diajukan ke Orjen TNI, tetapi ada yang cukup kepada Kepala Oditurat setempat saja dan rencana tuntutan tetap diperlukan untuk perkara yang besifat menonjol saja.

Rencana tuntutan yang diajukan tidak selalu beda, namun terkadang yang menjadi beban adalah kalau dalam rencana tuntutan yang diajukan hanya memuat tuntutan berupa pidana penjara, tetapi setelah turun dari Orjen TNI agar dituntut juga dengan pidana tambahan berupa pemecatan dari dinas militer. Persetujuan rencana tuntutan nantinya menjadi dasar dalam membuat surat tuntutan (requisitoir) yang nantinya 
dibacakan dalam persidangan di Pengadilan Militer

c. Wawancara dengan Mayor Laut (KH) I Made Adnyana, SH. dilakukan pada hari Kamis tanggal 11 Desember 2014 pukul 09.00 Wita.

Hasil wawancara dijelaskan bahwa Oditur Militer boleh dikatakan "ya atau tidak" independen. Ketidak bebasan harus membuatlaporankeOrjen TNIyangmembuat setiap Oditur Militer pada saat melakukan penuntutan menjadi kurang independen. Oditur Militer yang menyidangkan perkara lebih mengetahui fakta-fakta hukum di persidangan maupun undang-undang dan batasan minimal maupun maksimal tuntutan, termasuk di dalamnya ketentuan mengenai pemecatan terhadap prajurit TNI yang dirasa sudah tidak layak dipertahankan dalam dinas kemiliteran sesuai KUHPM. Oditur Militer mendasarkan pada pembuktian di persidangan, sehingga dalam menentukan tuntutan yang dirasa tetap dalam memenuhi rasa keadilan.

Kebijakan rencana penuntutan yang merupakan fungsi kontrol dari atasan tidak perlu dilakukan, tetapi terhadap fungsi kontrol ini seharusnya dilakukan oleh intelejen pengawas. Intelejen pengawas berfungsi ke dalam adalah melakukan pengawasan secara tertutup terhadap setiap tindakan Oditur Militer dalam menjalankan tugasnya. Sedangkan fungsi keluar intelejen pengawas adalah menelusuri rekam jejak terdakwa sejak perkaranya masuk ke Oditurat Militer, sehingga dapat dalam menilai kehidupan terdakwa lebih obyektif dan dalam melakukan penuntutan terhadap terdakwa nantinya dapat mendekati keadilan.
Menurut ketiga responden narasumber Oditur Militer yang telah diwawancari secara inplisit maupun eksplisit menerangkan dengan adanya kebijakan rencana tuntutan yang diberlakukan oleh Orjen TNI kepada semua Oditurat, jika tetap diberlakukan akan membuat Oditur Militer tidak independen dalam menjalankan fungsinya selaku penuntut umum di lingkungan TNI. Hal ini dikarenakan setiap Oditur Militer yang lebih mengetahui fakta-fakta hukum yang terjadi di persidangan Pengadilan Militer secara utuh namun pada saat akan membuat tuntutan, keputusannya menjadi tergantung kepada pimpinan, sehingga keputusan yang diambil tidak murni dari hati nuraninya. Kebijakan rencana tuntutan menjadikan Oditur Militer tidak dapat secara mandiri mengambil keputusan dalam membuat tuntutan maupun bertanggung jawab secara penuh terhadap perkara yang sedang ditangani.

Sebelummemperolehsuatukesimpulan tentang independensi Oditur Militer, maka penulis perlu terlebih dahulu menguji menggunakan teori sistem hukum. Menurut Lawrence M. Friedman, bahwa efektivitas penegakan hukum tergantung dari 3 (tiga) unsur sistem hukum yang mempengaruhi, yaitu struktur hukum (struktur of law), substansi hukum (substance of the law) dan budaya hukum (legal culture). ${ }^{10}$ Unsur yang paling dominan dari ketiga sub unsur pada teori sistem hukum adalah unsur struktur. Jika dikaitkan dengan struktur penegak hukum di lingkungan militer dalam hal ini Oditur Militer, maka kebijakan rencana tuntutan dari Orjen TNI sejalan dengan asas-asas di lingkungan peradilan militer

Anton Sutrisno, 2011, “Kemandirian Jaksa Sebagai Penuntut Umum (Analisis Terhadap Kebijakan Rencana Tuntutan)". (tesis), FHUI, Jakarta, hlm.14. 
dan perorganisasian militer terutama asas kesatuan komando (unity of command) dan asas rantai komando (chain of command) dalam rangka mewujudkan satu kesatuan penuntutan, namun tidak sejalan dengan teori sistem hukum karena dalam struktur telah ditentukan apa yang boleh dan tidak boleh dilakukan oleh suatu badan penuntutan melalui suatu aturan maupun prosedur baku yang berlaku.

Kemudian dalam menentukan sejauh mana perlunya kebijakan rencana tuntuan maka teori sistem hukum perlu disinergikan dengan teori berlakunya hukum oleh Robert B. Siedman yang menyatakan hukum dapat bekerja dan berfungsi tidak sekedar apa yang diharapkan oleh pembuat aturan, sehingga hukum berfungsi secara efektif dalam masyarakat, atau justru sebaliknya tidak efektif. Selain dari pada itu teori sistem hukum juga perlu disinegikan dengan teori fungsi (utilititiarisme) dari Jeremy Bentham yang menyatakan tujuan hukum adalah menjamin adanya kemanfaatan. ${ }^{11}$ Dari sini dapat dipetik suatu analisis bahwa kebijakan rencana tuntutan yang telah dikeluarkan Orjen TNI sesuai dengan asas kesatuan penuntutan maupun kesatuan komando, namun dari aspek efektifitas dan kemanfaatan berlakunya kebijakan rencana tuntutan justru membuat Oditur Militer menjadi tidak independen.

Kemudian mengenai sejauh mana perlunya kebijakan rencana penuntutan Orjen TNI tersebut, maka perlu dikaji menggunkan teori kebijakan hukum pidana dari Prof Barda Nawawi. Dalam teori

11 I Dewa Gede Atmaja, 2013, Filsafat Hukum Dimensi Tematis dan Historis, Setara Press, Malang, hlm.37. kebijakan hukum pidana disebutkan bahwa tujuan utama dari kebijakan hukum pidana adalah perlindungan masyarakat untuk mencapai kesejahteraan. Pencegahan dan penanggulangan kejahatan dengan sarana penal merupakan penal policy atau penal law enforcement yang operasionalisasinya melalui tiga tahapan, yaitu tahap formulasi (kebijakan legislatif), tahap aplikasi (kebijakan yudikatif/yudisial) dan tahap eksekusi (kebijakan eksekutif/administratif). Sesuai ketiga tahapan tersebut, tahapan formulasi memegang peranan penting dalam upaya pencegahan dan penanggulangan kejahatan, selain aparatur penegak hukum.

Tahapan formulasi merupakan tahapan yang paling strategis dari penal policy, karena apabila terjadi kesalahan dalam tahap formulasi aplikasinya justru akan dapat menjadi penghambat dalam upaya pencegahan dan penanggulangan kejahatan pada tahap aplikasi dan eksekusi. Dalam kaitan ini kebijakan rencana tuntutan yang dikeluarkan Orjen TNI sesuai asas kesatuan penuntutan dan merupakan fungsi kontrol terhadap setiap Oditur Militer yang akan melakukan fungsi penuntutan, namun dalam aplikasinya justru membuat Oditur Militer tidak independen dalam mengambil keputusan secara mandiri dan bertanggung jawab penuh terhadap perkara yang ditangani, sehingga kebijakan rencana tuntutan tidak efektif untuk diberlakukan, karena kebijakan tersebut tidak sejalan dengan "kebijakan pengembangan peradilan" yaitu sebagai upaya-upaya rasional untuk meningkatkan kualitas peradilan. ${ }^{12}$

\footnotetext{
12 Barda Nawawi Arief, 2008, Masalah Penegakan Hukum dan Kebijakan Hukum Pidana dalam Penanggulangan Kejahatan, Kencana Prenada Media Grup, Jakarta, hlm.9.
} 
3.2. Upaya-upaya yang harus dilakukan untuk menjadikan Oditur Militer yang independen dalam menjalankan fungsinya sebagai Penuntut Umum TNI.

Perubahan mendasar sebagai upaya yang dilakukan dalam mewujudkan Oditur Militer yang independen, terutama secara teknis yang perlu mendapatkan perhatian khusus. Mendasarkan pada teori fungsi hukum, yang menyatakan fungsi hukum dalam masyarakat adalah law as a tool of social engineering. ${ }^{13}$ Bahwa menurut Roscoe Pound, hukum bukan saja sebagai sekumpulan sistem peraturan, doktrin, dan kaidah atau azas-azas, yang dibuat dan diumumkan oleh badan yang berwenang, tetapi juga proses-proses yang mewujudkan hukum itu secara nyata melalui penggunaan kekuasaan. Oleh karena itu hukum menjadi alat legitimasi penguasa untuk berbuat terhadap rakyatnya, sehingga hukum menjadi alat pengendali penguasa terhadap rakyatnya.

Sejalan dengan teori fungsi hukum, untuk menjadikan Oditur Militer yang memiliki independensi dalam melaksanakan fungsinya dapat dilakukan upaya secara teknis yang terbagi dalam 3 (tiga) bidang yaitu:

\section{a. Bidang Teknis Penuntutan}

Upaya yang harus dilakukan bidang teknis penuntutan adalah dengan melakukan pendelegasian kewenangan penuntutan, termasuk di dalamnya pengendalian rencana tuntutan pidana dari Orjen TNI kepada

H.R. Otje Salman dan Anthon F. Susanto, 2010, Beberapa Aspek Sosiologi Hukum, Penerbit PT Alumni, Bandung, hlm.33.
Kepala Oditurat Militer /Oditurat Militer Tinggi, kecuali dalam perkara yang akan diajukan dengan tuntutan bebas/lepas dari tuntutan, terhadap perkara tindak pidana yang ancaman hukumannya lima tahun atau lebih, dan terhadap perkara tindak pidana yang sifatnya menonjol.

Dengan adanya pendelegasian kewenangan pengendalaian penuntutan kepada Kepala Oditurat Militer/Oditurat Militer Tinggi, akan akan lebih efektif dan efisien karena tidak semua tuntutan perkara dimintakan persetujuan Orjen TNI.

Pengendalian rencana tuntutan yang sebelumnya tertumpu di tangan Orjen TNI, dengan adanya pendelegasian pengendalian penuntutan, maka rencana tuntutan Oditur Militer yang dikirim melalui Kepala Oditurat Militer kepada Orjen TNI hanya terhadap perkara pidana yang akan diajukan dengan tuntutan bebas/lepas dari tuntutan, terhadap perkara tindak pidana yang ancaman hukumannya lima tahun atau lebih, dan terhadap perkara tindak pidana yang sifatnya menonjol

Selain pedelegasian kewenangan pengendalian rencana tuntutan, hal yang lebih penting terkait bidang penuntutan, Orjen TNI selaku pemegang kebijakan tertinggi dalam bidang penuntutan di lingkungan TNI harus membuat aturan berupa pedoman tuntutan pidana dalam perkara tindak pidana yang dijadikan acuan oleh setiap Oditur Militer dalam menentukan besaran tuntutan pidana. Pedoman tuntutan pidana di dalamnya memuat tentang hal-hal yang perlu diperhatikan setiap Oditur Militer dalam melakukan penuntutan, yaitu :

a. Tolok ukur menentukan tuntutan pidana berupa batasan pidana yang 
akan dijatuhkan secara terinci dalam pasal-pasal yang ada dalam KUHPM, KUHP dan Undang-Undang lainnya.

b. Faktor-faktor yang memberatkan dan meringankan tuntutan pidana yang dibuat secara detail dan terperinci.

c. Faktor-faktor dalam menuntut pidana percobaan atau pidana bersyarat.

d. Sikap Oditur selaku Penuntut Umum TNI terhadap putusan pengadilan.

\section{b. Bidang Pengendalian \\ Pengawasan}

Upaya yang harus dilakukan dalam bidang pengendalian dan pengawasan terhadap tuntutan Oditur Militer di setiap Oditurat harus dilakukan secara maksimal oleh Kepala Oditurat yang bersangkutan yang hasilnya dilaporan secara berkala kepada Orjen TNI. Dengan mempelajari hasil laporan berkala setiap Oditurat, Orjen TNI dapat menganalisi apakah rencana tuntutan maupun tuntutan dari Oditur Militer di jajarannya telah sesuai memenuhi stadard yang telah ditentukan atau tidak. Kemudian jika ditemukan tuntutan yang diduga tidak sesuai dengan aturan yang telah ditentukan, maka dapat dilakukan eksaminasi dan evaluasi terhadap rencana tuntutan atau tuntutan tersebut oleh Dinas Pengawas Teknis Oditurat Jenderal TNI.

Selanjutnya jika ditemukan unsur kesengajaan maupun motivasi lain yang dilakukan Oditur Militer dengan menuntut ringan terdakwa, maka Oditur Militer yang bersangkuan dapat dilakukan pemeriksaan oleh Dinas Pengawas Babinkum TNI. Apabila terbukti melakukan perbuatan tercela menyalahgunakan kekuasaannya untuk menguntungkan dirinya sendiri atau orang lain, Oditur Militer yang bersangkutan dapat dijatuhkan sanksi sesuai kesalahannya

\section{c. Bidang Pendidikan dan Pelatihan}

Rekruitmen terhadap para perwira TNI yang akan dijadikan sebagai Oditur Militer dan ditempatkan jajaran Oditurat selama ini diambilkan dari satuan-satuan hukum yang ada, baik dari TNI-AD, TNI-AL dan TNI-AU dengan pangkat minimal Kapten dari korp hukum yang berkualifikasi Sarjana Hukum. Pada saat rekruitmen para perwira yang akan dijadikan calon Oditur Militer tidak sedikit hanya berbekal Sarjana Hukum, tanpa sebelumnya mengikuti pendidikan khusus seperti Suspa Minlahkara maupun Kursus Jabatan Oditur Militer (Susjab Ormil).

Kemudian upaya yang harus dilakukan untuk mengatasi minimnya dalam bidang pendidikan dan pelatihan maupun bintekbintek tentang penuntutan yang diadakan oleh intern TNI, maka perlu kerja sama antara Mabes TNI dalam hal ini Otjen TNI dengan Kejaksaan Agung RI guna meningkatkan kemampuan setiap Oditur Militer dalam bidang penuntutan. Oleh sebab itu Mabes TNI sangat perlu menempatkan Perwira Penghubung (LO) di Kejaksaan Agung RI yang berfungsi mengkoordinasikan peningkatan kemampuan dan keterampilan teknis penuntutan bagi Oditur Militer, sehingga Oditurat Jenderal TNI dapat mengirimkan Oditur Militer yang berada di bawah komandonya untuk mengikuti setiap ada pendidikan dan pelatihan yang diadakan oleh Badiklat Kejagung RI. 


\section{PENUTUP}

\subsection{Kesimpulan}

Kesimpulan yang dapat tarik dari uraian pembahasan di atas adalah sebagai berikut:

4.1.1 Oditur Militer tidak independen dalam menjalankanfungsinya selakuPenuntut Umum TNI di Oditurat Militer III-14 Denpasar dengan berlakunya kebijakan rencana tuntutan Oditur Jenderal TNI. Hal ini dikarenakan Oditur Mliter yang lebih mengetahui secara utuh jalannya persidangan dan fakta-fakta yang terungkap dalam persidangan terhadap perkara yang ditanganinya, tetapi pada saat akan membuat tuntutan pidana menjadi sangat tergantung pada keputusan pimpinannya. Akibatnya setiap Oditur Militer tidak mampu mengambil keputusan secara mandiri sesuai hati nuraninya dan mampu bertanggung jawab penuh terhadap perkara yang ditanganinya.

4.1.2 Untuk menjadikan Oditur Militer yang memiliki independensi dalam melaksanakan fungsinya dapat dilakukan upaya-upaya secara teknis yang terbagi dalam 3 (tiga) bidang yaitu :

a. Bidang teknis penuntutan, yaitu dengan adanya pedelegasian kewenangan pengendalian rencana tuntutan pengendalian rencana tuntutan pidana dari Orjen TNI kepada Kaotmil/Kaotmilti, kecuali dalam perkara yang akan diajukan dengan tuntutan bebas/lepas dari tuntutan, terhadap perkara tindak pidana yang ancaman hukumannya lima tahun atau lebih, dan terhadap perkara tindak pidana yang sifatnya menonjol dan harus adanya aturan berupa pedoman tuntutan pidana dalam perkara tindak pidana yang dijadikan acuan oleh setiap Oditur Militer dalam menentukan besaran tuntutan pidana.

b. Bidang pengendalian dan pengawasan terhadap tuntutan Oditur Militer dilakukan secara maksimal oleh Kaotmil/Kaotmlti yang bersangkutan yang hasilnya dilaporan secara berkala kepada Orjen TNI, selanjutnya yang mempelajari hasil laporan berkala jika ditemukan tuntutan yang diduga tidak sesuai dengan aturan yang telah ditentukan, maka Orjen TNI dapat melakukan eksaminasi dan evaluasi terhadap rencana tuntutan atau tuntutan tersebut.

c. Bidang pendidikan dan pelatihan, dalam mengatasi minimnya bidang pendidikan dan pelatihan maupun bintek-bintek tentang penuntutan yang diadakan oleh intern TNI, maka perlu kerja sama antara Mabes TNI dengan Kejaksaan Agung RI guna meningkatkan kemampuan setiap Oditur Militer dalam bidang penuntutan, sehingga TNI dapat mengirimkan Oditurnya mengikuti Diklat tentang teknis penuntutan yang diselenggarakan oleh Badiklat Kejagung RI.

\subsection{Saran}

4.2.1 Agar pemangku kebijakan penuntutan tertinggi di lingkungan TNI, dalam hal ini Orjen TNI mengkaji ulang 
pemberlakuan kebijakan rencana tuntutan yang diberlakukan di seluruh Oditurat sejak tahun 2006 yang membuat Oditur Militer menjadi tidak independen dan tidak memberikan pelajaran bagi setiap Oditur belajar bertanggung jawab penuh dalam melaksanakan fungsinya selaku penuntut umum di lingkungan TNI karena tantangan tugas ke depan semakin kompleks, dan kebijakan rencana tuntutan seyogyanya dikembalikan sesuai ketentuan dalam Peraturan Panglima TNI Nomor: Perpang/5/II/2009 tanggal 27 Februari 2009 yang tercantum pada Bab V angka $28 \mathrm{~h}$ tentang tuntutan.

4.2.2 Agarpemangkukebijakandilingkungan TNI berupaya memperbaiki kualitas sistem penuntutan di lingkungan peradilan militer terutama dalam bidang teknis penuntutan, pengendalian dan pengawasan penuntutan, serta meningkatkan kuantitas dan kualitas pendidikan bagi setiap Oditur Militer sehingga mampu menjalankan tugas dan fungsinya secara profesional mengikuti perkembangan jaman.

\section{DAFTAR PUSTAKA}

\section{Buku :}

Abdussalam, H.R. dan Desasfuryanto, Adri, 2012, Sistem Peradilan Pidana, Penerbit : PTIK, Jakarta.

Arief, Barda Nawawi, 2008, Masalah Penegakan Hukum dan Kebijakan HukumPidanaDalamPenanggulangan Kejahatan, Kencana Prenada Media Group, Jakarta.

Atmaja, I Dewa Gede, 2013, Filsafat Hukum
Dimensi Tematis dan Historis, Setara Press, Malang.

Atmasasmita, Romli, 2010, Sistem Peradilan

Pidana Kontenporer, Kencana Predana Media Grup, Jakarta.

De Cruz, Peter, 2010, Perbandingan Sistem Hukum, Penerbit Nusamedia, Bandung.

Fajar, Mukti dan Achmad, Yulianto, 2007, DualismePenelitian, PensilKomunika, Yogyakarta.

Ibrahim, Johnny, 2007, Teori Dan Metodologi Penelitian Hukum Normatif, Bayumedia Publishing, Malang.

Ikahi, 2012, Varia Peradilan : Majalah Hukum Tahun XXVII No. 323 Oktober 2012, Penerbit Ikatan Hakim Indonesia, Jakarta Pusat.

Nurwantoko, Endro, 2012. "Mekanisme Rencana Penuntutan di Lingkungan Oditurat Jenderal TNI', Makalah pada Rakornis Babinkum TNI TA. 2012, Jakarta

Salam, Moch. Faisal, 2006, Hukum Pidana Militer Di Indonesia, Penerbit Mandar Maju, Bandung

Sianturi, S.R., 2010, Hukum Pidana Militer Di Indonesia, Babinkum TNI, Jakarta. Soekanto, Soerjono, 2014, Pengantar PenelitianHukum, PenerbitUniversitas Indonesia, Jakarta.

Sutrisno, Anton, 2011, "Kemandirian Jaksa Sebagai Penuntut Umum (Analisis Terhadap Kebijakan Rencana Tuntutan)". (tesis), FHUI, Jakarta. 


\section{Peraturan Perundang-undangan :}

Kitab Undang-Undang Hukum Acara Pidana (KUHAP).

Undang-Undang Nomor 31 Tahun 1997 tentang Peradilan Militer.

Undang-Undang Nomor 34 Tahun 2004 tentang Tentara Nasional Indonesia.

Undang-Undang Republik Indonesia Nomor 16 Tahun 2004 tentang Kejaksaan.

Undang-Undang Republik Indonesia Nomor 25 Tahun 2004 tentang Hukum Disiplin Militer.

Peraturan Panglima TNI Nomor : Perpang/5/ II/2009 tanggal 27 Februari 2009 tentang Petunjuk Administrasi Oditurat Dalam Penyelesaian Perkara Pidana.

\section{Internet :}

Fadzri, 2006, Rencana Tuntutan Bisa Jadi Komoditas, http://www politikindonesia.com/indexphp?k= hukum\&i-1004-rencana-tuntutanbisa-jadi-komoditas, (diakses tanggal 03 Mei 2014) 